\title{
Implementation of Local Participation as Part of Good Governance Principles: Galengdowo Village Wonosalam Sub-District, Jombang
}

\author{
Adelia Widiyanti \\ Department of Accountancy, Faculty of Economic and Business \\ Universitas Airlangga, Surabaya, Indonesia \\ Email: adeliawd22@gmail.com
}

\begin{abstract}
The purpose of this study is to reveal the local participation as part of the good governance principles in the management of village fund based on local wisdom in Galengdowo Village. Previous research only focused on the practical in the formalities of budget planning. In this mini thesis, researcher attempt to show overall participation beyond the formalities. An ethnomethodology approach will help to reveal the local wisdom that occurred in Galengdowo Village in management of village fund. The local wisdom will help society to participate in planning, implementation, and accountability in the management of village fund.
\end{abstract}

Keywords: Village fund; ethnomethodology; local wisdom; participation; good governance.

\section{ABSTRAK}

Tujuan penelitian ini adalah mengungkapkan partisipasi lokal sebagai bagian dari prinsip good governance dalam pengelolaan dana desa berdasarkan kearifan lokal di Desa Galengdowo. Penelitian sebelumnya hanya berfokus pada praktek perencanaan anggaran secara formalitas. Penelitian ini mencoba menunjukkan keseluruhan partisipasi lokal di luar formalitas perencanaan anggaran. Pendekatan etnomologi akan membantu mengungkapkan kearifan lokal yang terdapat di Desa Galengdowo dalam pengelolaan dana desa. Kearifan lokal akan membantu masyarakat untuk berpartisipasi dalam perencanaan, implementasi, dan akuntabilitas pengelolaan dana desa.

Kata kunci: Dana desa, etnometodologi; kearifan; lokal, partisipasi; good governance.

\section{INTRODUCTION}

Village will get supports 1 Billion Rupiah from state budget under Law No. 6 Year 2014. Every village which currently amounts to 72 thousand in Indonesia will have budgets around 800 Million to 1.4 Billion Rupiah adjusted for each village based on the wide, population, and level of needs in the village. These fund transfer is only for village. Kelurahan is not included in the program budget recipients because it is the part of government structures (Astutik, 2016). The point of this fund transfer is to emphasis purely on village development, instead of the government structure. State government would like to provide workshop to the head of village to manage the transfer fund. The village government should be able to apply the principles of transparency and accountability in the funding management of the village. Ministry of Internal Affairs has been declared Permendagri
No. 113 Year 2014 about management of village fund in order to achieved transparency, accountability, and participative in village. Every village has to perform their funding system proper with the regulation. Implementation of this law must be surveillance by state and regional itself because of the big responsibility which belongs to the village.

From statement above, this research is conducts to know the participation among society to perform good governance in management of Village fund with local wisdom of the community to build an extraordinary performance. Furthermore, this research has purposed to specifically on the management of Village fund instead of previous research which already done in the past. Therefore, this research is titled Implementation of Participation as One of Good Governance Principles: Case of Galengdowo Village, Wonosalam sub-district, Jombang). 
Based on the research background statement above, the objectives that defined in this research is to determine the society implementation of participation as one of good governance principles in Galengdowo Village, Wonosalam sub-district, Jombang to implement one of good governance, participation, and any obstacle which encountered the implementation.

\section{UU No. 6 Tahun 2014}

The UU No. 6 Tahun 2014 about Village or Desa as a product of politics policy in the end of President Mr. Susilo Bambang Yudhoyono and give duties to the next President, Mr. Joko Widodo. The important aspect of implementation the UU No. 6 Tahun 2014 is about Village fund budgeting. This aspect has been further informs in Peraturan Pemerintah No. 43 Tahun 2014. The concepts of this Law of Village are; 1) Village is trying to be independent to resolve their own problems, physically and non-physically within their budgeted, 2) Village must be increase participation and mutual assistance in the society through the development of the village, 3) Village must make their own plans to the development of the village through the welfare of society, 4) Village must still conduct monitoring though the development of the village, 5) Village must increase their human resources of the village officials as the as an executors of the development, social, and services to the society.

\section{Peraturan Bupati Jombang No. 5 Tahun 2016}

According to the Permendagri No 113 Tahun 2014 about the management of village funding is an improvement of the previous regulation, Permendagri No. 37 Year 2007. The Peraturan Bupati Jombang No. 5 Tahun 2016 about the Procedures of Allocation, Distribution, Use, and Accountability Village fund in Jombang District for 2016 is the differential of the Ministry Regulation above which performed more specific regulations that held for local government to present the best administration over the budgeting process. The concept of this regulation are to ease the administration process over all of the local government in Jombang, to prevent any misinterpretation and or misplaces of the National Budgeted over the project activities in Jombang.

\section{Good Governance}

Based on the Mardiasmo (2002), Good governance is the development view or new paradigm under public administration. The good governance include all of the mechanism, process, and the organization where the society explain their interest, aspiration, and fulfillment their right and obligation. They are shifting from the government towards governance which emphasizes the collaboration in equality and balance under government, private sector, and civil society. The other definition explained by Stoker (1998) that there are five propositions to respond an aspects of governance. The five propositions are:

1) Governance refers to set of institutions and actors that are drawn from but also beyond government.

2) Governance identifies the blurring of boundaries and responsibilities for tackling social and economic issues

3) Governance identifies the power dependence involved in the relationships between institutions involved in collective action

4) Governance is about autonomous self-governing networks of actors

5) Governance recognizes the capacity to get things done which does not rest on the power of government to command or use its authority.

These propositions above must be applied by government to implement the good governance and achieve their own and state vision. Finally, the good governance, management of Village fund must be based on the principles of good governance itself: transparency, accountability, responsibility, and participation.

\section{Transparency}

Transparency is openness in decision making process and exposure in expressing material and relevant information about the agency itself. Information is the most materials of this transparency because they have to be transferred to the user as if transparency in government bodies. According to the regulation by Permendagri No. 13 Tahun 2006 about the guidelines for management of Village fund said that transparency is the principle of openness that people or society enable to find and could access the information related the financial statement of village. With transparency characters, people or society are guarantee the openness and access the information related to the government itself, such as information about policy, the process of planning and implementation, until the output achieved. It must be cover all of aspects behind the government so the expected outcomes of the transparency itself is to produce the fairness of politics, tolerant, and regulation made by society (Bappenas, 2003). Based on National Development Planning Agency, transparency can be measured by several indicators. The indicators are systems 
which ensure openness and standardization for all of public services, provide public inquiries about public policies and services until process in public sector, and provide a report and spread an information and or deviation in public service which held by public officer.

\section{Accountability}

Accountability is clarity of function, structure, systems, and accountability of organization so the management runs effectively. It is a responsibility to give a accountability or answer and performance explanation an organization to someone who have a rights and authorize to request an information and accountability on something. According to LAN \& BPKP (2000), there are some principles to do an accountable in government:

a. The organization must have commitment from top level to low level to do an accountability in their performance

b. It must a system which guarantee users of the sources regularly based on current legislation

c. It must be able to show the level of achievement of goals and objectives that have been set

d. It must be orientation to achieve vision and mission and then the results and benefits

e. The organization must be truthful, objective, transparent, and innovative as a catalyzer of management changing in government.

\section{Participation}

Every citizen has a right in decision making, either directly or through the intermediaries media that represent their interest legitimacy. The participation is based on freedom of associated and speech constructively through the organization. Under the Permendagri No. 37 Tahun 2007 about management of Village fund, society must be participative, which is mean involve and active in the development process of society itself. Participation by society in determination of public policy would assist the fulfillment of accountability principle and prevent improper policies in local government. Based on the Cohen (1977), participation are divided into four parts of mechanism: Participation in decision making, implementation, benefit, and evaluation. In other hand, there are some principles and indicators to do participation in the organization (Taufik, 2013)

\section{Concept of Local Wisdom}

Local wisdom is consists of two words; local which is mean a place while wisdom is a wise or thoughtful. Generally based on the previous means, local wisdom is a local ideas which are truthful, full of wisdom, have a good value, implemented and followed by the member of society. According to Ernawi (2009), local wisdom is a human effort using his intellect cognition to act and behave towards something, an objects or events that occur in given space and time. It can be specialized with etymology, wisdom itself is an ability of someone to use his own intellect cognition to act and behave as a result of assessment towards objects or events.

In other hand, anthropology said that local wisdom is better known as local genius, which is not separately with cultural identity. Personality of national culture led a nation to be able absorb and process the appropriate foreign culture based on identity, characters, and ability of its own (Ayatrohaedi, 1986). Local genius is a truth that has been tradition in a place. Some other points, local wisdom are a compound of Value of God and some of existence value in the place, so it is a cultural product in the past that should be continuously hold ever after.

\section{RESEARCH METHODOLOGY}

In this research, researcher used qualitative approach. According to Bungin (2009), qualitative method is a research approach which use data basis data used are written or spoken sentences, behavior, facts or phenomena or events, knowledge, and the object of study based on the observation in the field. The process of qualitative research is not as simple as quantitative research in the development of sciences. The method of this research is an ethnomethodology approach. The ethnomethodology is an approach from the anthropology study that have been used to understanding about human living. Based on Spradley (2007), the purpose of the ethnomethodology study is to understanding a point of view of native inhabits, relation to their life, to earned viewpoint of their world. Researcher must understand every behavior from some events that researcher wants to know, directly and or indirectly. Ethnomethodology is not only learn about society, but also learn from the society itself.

The scope of this study is a border to make this research is more focus so it could be widened in other issue. The border for this research is:

a. The Medium Term Development Planned (Rancangan Pengembangan Jangka Menengah/ RPJM) of Galengdowo Village for 2014-2019

b. The Government Work Planned (Rencana Kerja Pemerintah/RKP) of Galengdowo Village for 2016

c. Financial statement of local government: Galengdowo Village, Wonosalam sub-district, 
Jombang for The Local Government Budgeted (APBDes) for year 2016 which include the cash book, the bank book, and the additional tax book.

d. The Budget Planned (Rencana Anggaran Biaya/RAB) of Galengdowo Village for 2016

e. The Accountability Report (Laporan Pertanggung Jawaban/LPJ) of Galengdowo Village for 2016 which include the request payment letter (Surat Permintaan Pembayaran/SPP).

f. Minutes of Meeting of Development Planning meeting (Musrenbang) of Galengdowo Village for 2016

g. The local wisdom of Galengdowo Village

Types of data that collected by researcher for this research is divided into two: Qualitative data by field research as an observation and quantitative data by documentation, archieve footage, interview, and direct observation. The data collection techniques are preliminary survey, study of literature, and field study. Researcher focused with the data analysis techniques from Spradley (2015) for analysis the information that achieved by researcher. Within the qualitative research, Moleong (2002) has stated that to make a data validity, researcher could use a Data Triangulation techniques. The type of the data triangulation that researcher used is the triangulation of source which comparison and checking the trustworthiness degree of the information that have been earned with the different time and tools in the qualitative research, it could be done by: (1) compare between the direct observation with the interview notes; (2) compare with what people said in the front stage and back stage; (3) compare the perspective, arguments, and viewpoint what society said and the executive said; (4) compare the interview notes with some of the related document.

\section{DISCUSSION AND INTERPRETATION}

\section{The Local Wisdom in Galengdowo Village from Kenduri Salak}

Wonosalam is a region where placed in the foot of mountain Anjasmoro. Everyone knows about Wonosalam like what people knows Batu in Malang or Puncak in Bandung. Wonosalam is a place related to the camping ground and outbound place. The most well know event held by the Wonosalam sub-district is Kenduri Durian, an annual event for introducing best durian comes from Wonosalam. Everyone in East Java has known that Wonosalam is the best producer of durian. If someone has come to the Jombang, they do not forget to buy any durian from Wonosalam.
Learning from durian, the Regional Government of Jombang has known that it could be a tradition or ceremonial to represent that Jombang has something different with other region in Indonesia and so, it held a Kenduri Durian.

So does Wonosalam, culture have been attached to society in Galengdowo Village seen as a collection of pattern in human behavior that relying on creativity and belief for life and so the heritage culture still purely until now. After interviewing the head of Galengdowo Village, researcher could understand some of local wisdom that still existed in the society such as Kenduri Salak, Upacara 1 Suro (1 ${ }^{\text {st }}$ Suro Ceremonial), and presenting "Good Day" and Tumpengan in every event. Researcher could not join every ceremonial event that held by Galengdowo Village because of the time, but researcher could understand and feel the atmosphere by the interviewed and watched the videos about the ceremonial event. From the ceremonial themselves, researcher could interpret and conclude many local wisdom that explicit or implicit that stated by the informant in this research.

Table A. The Domain of Local Wisdom in Galengdowo Village

\begin{tabular}{|c|c|c|}
\hline No. Cover Term & $\begin{array}{c}\text { Semantic } \\
\text { Relationship }\end{array}$ & Included Terms \\
\hline 1 Kenduri Salak & $\begin{array}{l}\text { As a reason to } \\
\text { organize }\end{array}$ & $\begin{array}{l}\text { Participation from } \\
\text { society } \\
\text { Show off the best } \\
\text { salak producer } \\
\text { Praise to God about } \\
\text { harvest time }\end{array}$ \\
\hline $\begin{array}{ll}2 & 1^{\text {st }} \text { Suro } \\
& \text { Ceremonial }\end{array}$ & As a part of & $\begin{array}{l}\text { Heritage Culture } \\
\text { Hope a peace for } \\
\text { village } \\
\text { Sesajen }\end{array}$ \\
\hline $\begin{array}{l}3 \text { Presenting } \\
\text { "Good Day" and } \\
\text { Tumpengan }\end{array}$ & As a attribute of & $\begin{array}{l}\text { Look for a good day } \\
\text { Villager culture } \\
\text { Ritual / Tradition }\end{array}$ \\
\hline
\end{tabular}

From the best three ceremonial things that always held by Galengdowo Village it could be conclude that Galengdowo Village has a good participation enough from their society. It is a tone with the theory that have been represent a good governance by the Haryanto and Arifuddin (2007), the principles of doing the good governance there are participation, transparency, and accountability in the government and development. A good participation from the society is a needed to actualized good village governance in management of Village fund in Galengdowo Village. And so, to represent the good governance in the management of Village fund, will be tested by the tools and information that have been achieved in Galengdowo Village. 
Accountability in Management of Village fund

Based on the principles above are clearly stated that management of Village fund must be opened through the society and the outcomes will be represent by the Village Regulation (Peraturan Desa). The principles show the commitment under stakeholders that the management of Village fund must be fulfilled the good governance in the society. The statement from the Head of Galengdowo Village give a signal that Desa Galengdwo has represent a good village governance based on the Regional Regulation that created by Jombang District in the management of Village fund. It indicates that Galengdowo Village has implements the principles to create a participation in the society within transparency, accountability, and responsive by the local government. Participation is an involvement by every citizen in decision making, either directly or through their representative institutions (Tjokroamidjojo, 2000). For the further explanation, the implementation of the principles could be detected from the planning the budgeting, implementation of management of Village fund, and then accountability of the application of Village fund.

\section{Planning of Budget}

Participation is needed for the future accomplishment to create good governance in the local government. Based on Tjokroamidjojo (2000), participation principles is every citizen involve in the decision making directly or through the institutions that represent an interest. The participation could be built by the empowerment process based on Oakley and Marsden (1984) contains two tendencies; First, the empowerment process that emphasizes the process provide and transfer some power, force, and or community ability to be more empowered; Second, emphasis on the process of stimulating, encouraging or motivating the individuals which have capability or empower and or determine the options based on dialogue process (Pranarka and Onny, 1996). In the budgeting process of Village fund, Galengdowo Village has been implemented the participation for empowerment the society through the development of village. it could proof by the interview below.

"Kami selalu mengundang masyarakat untuk mengikuti musrenbang. Terutama kepada tokoh masyarakat yang disegani oleh masyarakat. Dan masyarakat sangat antusias sekali tidak jarang mereka berpartisipasi aktif dalam musyawarah tersebut seperti memberi masukan" (interview with Mr. Sapto, December 23rd 2016).
Its statement is supported by the following statement. "Kalau perencanaan kami mulai dengan musyawarah dusun. Masing-masing kepala dusun mengadakan rembug di setiap dusun untuk kegiatan di tahun depan namun tetap pada koridor RPJM. Lalu setelah itu dibawa ke musrenbang. Di musrenbang kita pilah mana yang menjadi prioritas. Selanjutnya, dibawa menuju APBDes. Jadi APBDes sangat mengacu pada musrenbang yang telah dilakukan" (interview with Mr. Sapto, December $23^{\text {rd } 2016) . ~}$

This mechanism is the step stone for society in the village to show off their aspirations and comments for the development of village and also as a tool for society to understanding the accountability principles on the management of Village fund.

Based on the selected proof, the participation from attendances for decision making and local revenue contribution from Galengdowo Village is not really good. It indicates that some people are not interest more with the meeting. Moreover, some of them are only to fulfillment the invitation. This attendance is important and urgent because it could support the local government to understanding the society in village, purposing the agendas and service priority, and the development of service program based on the needs and aspiration from society. Even the own revenue from village is relatively small, but society in village are mutual assist for doing everything for development of village such as Kenduri Salak, is purely mutual assistance events from society.

In other hand, there is someone from Family Welfare Guidance (Pembinaan Kesejahteraan Keluarga/PKK, Mrs. Widji, has been said about the musrenbangdes. She said the musrenbangdes has been set by the village had less value because participants could not freely participate. They have been show off their aspiration in the meeting but for the feedback from their aspirations are not fully accepted by the local government because of the regulation that set by regional government, Jombang. The Regional Regulation No. 5 Year 2016 has been set all the matter from top to the bottom in the management of Village fund. It just told specifically with the range, nominal, and also the events that must be held under the Village fund budget. It is a tone with the next statement from Mrs. Widji. The statement above represent the budgeted is not understood with the nature and needs of the village itself. The regulation from region is good for the village but somehow they just do not fit through the needs of the village. In other hand, Mr. Setiyo as a Head of project management field has been said the budgeting process is quite good so their projects have no loss and or gain. 
In Jombang, every village must following the regulation that set to achieve the objectives of the Village fund itself within the priority scale on The Medium Term Development Planned (RPJM). Unfortunately, the regulation told much to the local government. Researcher is not agreed with the regulation because they allocated equally from one village to others. Every village has their own needs and priority that must be filled by the Village fund. Somehow in other perspective, the regional government wants to make a good administration and make everything easier than the local government make their own budget. According to the functional, Village fund only used for infrastructure things for development of village. The operational things would be covered by Allocation of Village fund (ADD). So, the planning must be agreed and transparency to all of the people in society and it could be accountable. The accountability of the planning, all of the staff of local government and the one who come to the meeting must tell outcomes to the society. It shows that Galengdowo Village has been applied transparency and accountability principles even though not perfectly. The indicator is local government of Galengdowo Village has tried their best to do the good governance to organization. Then, the local government is open to the criticism from society to be better, from the planning until postproject.

\section{Implementation of Village fund}

Based on the ethnomethodology study, the researcher could understand the participation process in Galengdowo Village. According to Spradley (2007), researcher makes taxonomy to organize the interview process that held before to understanding the knowledge within the structural questions.

Table B. Taxonomy of Local Participation in Galengdowo Village

\begin{tabular}{|c|c|c|}
\hline \multirow{2}{*}{ 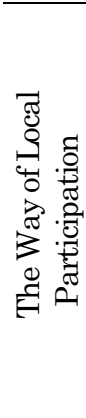 } & $\begin{array}{l}\text { Join Family Welfare } \\
\text { Guidance }\end{array}$ & $\begin{array}{l}\text { Regular gymnastics } \\
\text { Join gymnastics } \\
\text { competition } \\
\text { Mother Welfare } \\
\text { Movement (GSI) } \\
\end{array}$ \\
\hline & $\begin{array}{l}\text { Join Project Management } \\
\text { Field } \\
\text { Join Youth Organization } \\
\text { Kenduri Salak } \\
1^{\text {st }} \text { Suro Ceremonial } \\
\text { Kenduri Durian }\end{array}$ & $\begin{array}{l}\text { Make a drainage } \\
\text { Make a pipeline } \\
\text { Learning volley }\end{array}$ \\
\hline
\end{tabular}

Based on the analysis of the taxonomy above, researcher has understanding the new relationship the stated attribute. The attribute always related to the original stated from the informants.
Researcher found any double relationship from one domain to other domain. Finally, researcher proposes further questions for the informants for added new information. The participation among the society in the village has been set long time ago before it have been set by the regulation from national, regional, and also local government itself.

"Since a long time ago the people are very cling to their culture. They offer offerings voluntarily, without being commanded. While doing their activities, they also wait for a good day. It has become a habit and can not be changed" (interview Mr. Wartomo December 27th 2016)

"Before I moved here, the people were very obedient and had high mutually cooperation. People here are very good people, they have good relations with the government, never opposed" (interview Mr Sapto December 21 ${ }^{\text {st }}$ 2016)

From the statement above it represent that the participation from the society in the implementation of Village fund is very good and cannot be separated by the culture of the village. Long time ago, the village has been very good culture and obey with the one they believe and also highly participate with the every single activities that held by the government. It represents that along the implementation of participation under the good governance principles, society in Galengdowo Village have been participated active through the local government. They are really comply with the one they believed, such as God, The One they Believed, and local government.

\section{Accountability of Village fund}

The accountability process of Village fund in Galengdowo Village is integrated with the accountability of Local Budgeted. They have to obey the Regional Regulation No 5 Year 2016 about The Procedures of Allocation, Distribution, Use, and Accountability Village fund in Kabupaten Jombang for 2016. The regulation is a tool for the law base of village funding, the source of village revenue, the management of Village fund, and the revenue budgeted and the disbursement of the village. The management of Village fund must be effective and efficient, transparency, and accountability because it a source of village revenue and must be accountable transparency with the society and the state government as a giving authority. The accountability process through the regional government is done within twice a year. It stated by the treasurer of the local government. The good communication between the local and regional government represents that misunderstanding and inappropriateness around the management process is few. 
As an awardee of Swasembada village, they have represents that Galengdowo Village is a good village in every single aspect that related to the good governance. It is a tone with the following activity that related through the accountability process in society. For the head of village organization explained that the accountability process held every month and must be submitted to local government to be handle. The accountability report must proof by the evidences.

The accountability process could help local government increase participation in the society because they understand more and believe that local government has tried their best to do the administration process. Then the society would help the local government for the development of village. The evaluation process on the Village fund program is not only in musrenbangdes, but also the meeting before the financial report inspected by inspectorate. In the meeting, society would help to be understood about the flow of funds from the state until the local itself and distribute to the program based on the Medium Term Development Planned (RPJM). This evaluation meeting process would help society to actively participate to give any suggestion and correction in the management of Village fund. Its consistent with the statement from Tjokroamidjojo (2000) about the transparency must be known with all of the stakeholders for the improvement. The relationship between the local government of Galengdowo Village with their stakeholders must consist with the good governance principles: participative, responsive, transparency, and accountable around the planning, implementation, and accountability process in the management of Village fund. They have implemented all the principles but also need evaluation from time to time to be perfectly implemented and always improve in management of Village fund in Galengdowo Village.

\section{Interpretation}

From the statement preliminary study it could be interpret that the participation among the management of Village fund in Galengdowo Village, Wonosalam sub-district, Jombang in year 2016 have been based on the good governance principles by the (Tjokroamidjojo, 2000). Within the ethnomethodology study from Spradley (2007), the domain for every local wisdom that stated before has opened new relationship with the attribute one. The ethnomethodology helps researcher find out what local wisdom that affected the participation. Then, the result help researcher understand that the local wisdom affected the local participation over the activities that held by local government. Local wisdom increased the belonging feeling through the activities around the village. Even though they have good implementation, they must always evaluate and improve to be better based on the conditions and the regulation itself. Based on the preliminary discussion, the society in Galengdowo Village is actively participate along the activities and also compliance with the regulation that held by local government.

\section{CONCLUSION AND SUGGESTION}

The conclusion of this research based on the previous research question is:

1. Galengdowo Village, Wonosalam sub-district, Jombang has been implemented one principle of good governance, participation among their society in the management of Village fund. The local government could not be done the things without any support from their society.

2. Based on the preliminary study about ethnomethodology, the people in the village have been understand well and always do their local wisdom through their daily activities which done by the local government. First of all, the Kenduri Salak event. In this event, the researcher could understand that society in village have a high sense of caring.

3. The local government of Galengdowo Village, under Mr. Wartomo, has been showed their best performance. Within the good leadership could deliver the village to be The Swasembada Desa in Wonosalam sub-district.

The suggestion that could be suggested for the future researcher based on this research is:

1. More explanatory about the ethnomethodology study and or other anthropology studies. Accounting is not only about counting, but also the act and react from the around the number that stated in the financial report.

2. The length of the time research. In the ethnomethodology study must around 6 months of the research and could less nor more.

3. The different types of object in Galengdowo Village. A lot of object that could be found in the village that interesting enough to be research such as agricultural, cattle farm, and many more.

\section{REFERENCES}

Astutik, T. P., Yulianto. (2016). Good Governance Pengelolaan Keuangan Desa Menyongsong Berlakunya Undang-Undang No. 6 Tahun 2014. Berkala Akuntansi dan Keuangan Indonesia, Vol. 1, 1-14. 
Ayatrohaedi. 1986. Kepribadian Budaya Bangsa (Local Genius). Jakarta.

Bungin, B. 2009. Penelitian Kualitatif. Jakarta: Kencana.

Badan Perencanaan Pembangunan Nasional. 2003. Indikator \& Alat Ukur Prinsip Akuntabilitas, Transparansi \& Partisipasi. Jakarta

Cohen, U. 1977. People's Participation in Community Development. Marsland Press.

Ernawi, I. S. 2009. Kearifan Lokal Dalam Perspektif Ruang: Kearifan Lokal dalam Perencanaan dan Perancangan Kota; Untuk Mewujudkan Arsitektur Kota yang Berkelanjutan. Malang.

Haryanto, S., dan Arifuddin. 2007. Akuntansi Sektor Publik. Semarang: Universitas Diponegoro.

LAN \& BPKP. 2000. Akuntabilitas dan Good Governance, Modul 1 dari 5 Modul Sosialisasi Sistem Akuntabilitas Kinerja Instansi Pemerintah. Penerbit LAN. Jakarta

Peraturan Menteri Dalam Negeri No. 113 Tahun 2014 Tentang Pengelolaan Keuangan Desa.

Peraturan Menteri Dalam Negeri No. 37 Tahun 2007 tentang Pedoman Pengelolaan Keuangan Desa

Peraturan Pemerintah No 43 Tahun 2014 tentang Peraturan Pelaksanaan Undang-Undang No 6 tahun 2014 tentang Desa.
Peraturan Bupati Jombang No 5 Tahun 2016 tentang Tata Cara Pengalokasian, Penyaluran, Penggunaan dan Pertanggungjawaban Village fund

Undang-Undang No. 6 Tahun 2014 Tentang Desa.

Mardiasmo. 2002. Otonomi \& Manajemen Keuangan Daerah. Yogyakarta: Andi.

Moleong, L. J. 2002. Metode Penelitian Kualitatif. Bandung: Remaja Rosdakarya.

Oakley, P., Marsden, D. (1984). Approach to Participation in Rural Development. Geneva.

Pranarka, P., Onny. 1996. Pemberdayaan, Konsep, Kebijakan, dan Implementasi. Jakarta: Centre for Strategic and International Studies.

Spradley, J. P. 2015. The Ethnographic Interview. Waveland Press Inc.

Spradley, J. P. 2007. Metode Etnografi (2 ed.). Yogyakarta: Tiara Wacana.

Stoker, G. 1998. Governance as theory: Five Propositions. (Blackwell Publisher).

Taufik, T. 2013. Pengelolaan Keuangan Desa Dalam Sistem Keuangan Negara Republik Indonesia. Jurnal Ekonomi 17.

Tjokroamidjojo, B. 2000. Good Governance (Paradigma Baru Manajemen Pembangunan). Jakarta: UI Press.

Widjaja, H. 2003. Otonomi Desa. Jakarta: PT Raja Grafindo Persada. 